\title{
TESTS OF PURCHASING POWER PARITY WITH STRUCTURAL BREAK IN THE MEXICAN ECONOMY
}

\author{
Noé Arón Fuentes* \\ Tecnológico de Monterrey, Campus Monterrey
}

Alberto Godinez Plascencia

Departamento de Estudios Económicos, El Colegio de la Frontera Norte

(Received 1 April 2004, accepted 16 August 2004)

\begin{abstract}
Mexican studies of Purchasing Power Parity hypothesis (PPP) have reported mixed results, and most of them do not account for structural breaks. The following study presents further findings of the relation of PPP for the Mexican's economy using twelve different definitions of exchange rate, different base year and trade-weights with structural change. Depending on the definitions of the concept of real exchange rate, some results are supportive that purchasing power parity holds as a long-run concept for the Mexican peso, while others are not.
\end{abstract}

\section{Resumen}

Los trabajos de investigación sobre la hipótesis de la Paridad del Poder de Compra (PPP) han arrojado resultados mixtos; además, la mayoría no considera los cambios estructurales. El objetivo del trabajo es contrastar la hipótesis PPP para la economía mexicana tomando en cuenta los cambios estructurales de la relación bajo doce diferentes definiciones del tipo de cambio, diferentes años base y diferentes ponderaciones de comercio. Dependiendo de las definiciones del tipo de cambio real, algunos resultados confirman la hipótesis PPP como una relación de largo plazo para el peso mexicano, mientras los resultados de otras definiciones no la confirman.

JEL classification: C12, C22, F31

Keywords: Purchasing Power Parity (PPP), Structural Breaks, Mexico

* Departamento de Estudios Económicos, El Colegio de la Frontera Norte. Blvd. Abelardo L. Rodrígnez num. 2925, Zona Río, Tijuana, B.C., México. C.P. 22320. Telephone: +52 (664) 6316314. E-mails: afuentes@colef.mx and gopa@colef.mx

The first author is professor in the Escuela de Graduados de Administración Pública y Política Pública (EGAP) of Tecnológico de Monterrey, Campus Monterrey, in sabbatical year by El Colegio de la Frontera Norte. The second author is professor in the Departamento de Estudios Económicos, El Colegio de la Frontera Norte. 


\section{Introduction}

This paper investigates the long-run relationship on real exchange rates to study the validity of Purchasing Power Parity (PPP) in the Mexican's economy. Most empirical studies about the validity of PPP do not account for structural change. This misspecification problem from structural breaks, however, has been an issue related to stationary investigations such as the unit root test. As shown by Perron (1989), a structural break may make an otherwise stationary variable appear to be a unit root process. In this context, it is important to account for structural change in studying the validity of PPP in the economic system. Besides the lack of consideration of structural change, most studies of PPP have problems regarding the definition of real exchange rate, the base year and the trade-weights used. The following presents further study of the relation of PPP for the Mexican's economy using twelve different definitions of exchange rate, different base year and trade-weights (i.e., using trade-weights shares, major trading-weights, import-weights, tradable and non-tradable goods weights and gross domestic product, wholesale price index and consumer price index) with structural change.

This paper is organized as follows. Section two discusses the PPP theory, Section three describes Perron's methodology of unit root test with structural break. Section four presents twelve different empirical definitions of real exchange rate. Section five presents the data and sources of information. Section six reports the result of testing for stationarity of the real exchange rate. Finally, we present the conclusions.

\section{The Theory of Purchasing Power Parity}

There are three concepts of PPP which are usually used in explaining why goods in one country should cost the same as identical goods in another country. The law of one price explains the relationship of exchange rate with the prices of an individual good in two different countries. Absolute PPP explains the relationship of the exchange rate with general price levels of the two countries, whereas relative PPP explain the relationship of the exchange rate with the inflation rates in different countries.

The law of one price states that the cost of identical goods sold in the two countries should be identical, assuming no trade restrictions or transportation costs. The theory of pure international trade implies that autarkic price differences between countries may exist because of technological or factor endowment differences, given that the regular conditions are satisfied. But with trade under perfect competition renders that difference inconsequential, implying market forces the law of one price to be held. One can not, however, easily dismiss transportation costs and trade restrictions. For example, the cost of transporting goods from one country to another limits the potential profit from buying and selling identical goods at different prices. In addition, tariffs and other trade restrictions drive a wedge between the prices of identical goods in different countries. Therefore, instead of focusing on a particular good or service when applying the concept of PPP, the law of one price is stated in terms of general price level. 
The extension of the law of one price to general price level takes the form of the strong, or absolute, version of PPP, which states:

$$
S_{t} P_{t}^{*}=P_{t}
$$

where $S_{t}$ is the nominal exchange rate defined as the units of domestic currency per unit of foreign currency, $P_{t}$ is the domestic price level and $P_{t}^{*}$ is the foreign price level. This expression requires that the domestic price index has the same functional form as the foreign price index and the same goods enter each country's market basket. Let $P_{i}$ be the price of the i-th good in foreign currency. Then,

$$
P=\prod_{i=1}^{n} P_{i}^{\alpha_{i}} \text { and } P^{*}=\prod_{i=1}^{n} P_{i}^{* \alpha_{i}^{*}}
$$

where $\alpha_{i}$ and $\alpha_{i}^{*}$ represent a system of weights with $\sum \alpha_{i}=\sum \alpha_{i}^{*}=1$. These indices are justified by standard consumer theory under the assumption that the consumer devotes a fraction $\alpha_{i}$ of his or her budget to the good, which is given independently of relative prices. So the relative welfare or utility among consumers depends on their relative purchasing power.

Under PPP, changes in the bilateral exchange rate over any period of time are determined by the changes in the two countries' relative prices. Because aggregate price level and exchange rate are both endogenously and simultaneously determined, however, PPP can be viewed as an equilibrium relationship rather than as a theory of exchange rate determination. In addition, if the law of one price holds for all goods and if price levels in different countries are constructed in the same way, the absolute version of PPP should hold.

The absolute version of PPP can be accepted as a theoretical proposition within the context of a hypothetical economy. Objections arise when it is applied as an empirical proposition. First, transportation costs and other obstacles to trade do exist, implying that the location of delivery matters. The existence of price differences of a given good in different location, however, does not indicate a market failure. Market efficiency nonetheless obtains, provided that the price system incorporates all the costs of trade obstacles. Thus, price differentials could reflect the cost of obstacles to trade between regions. Second, there may be a measurement problem. Price levels in different countries are calculated using price indices considered imperfect. Specifically these are based in different years, include different market of goods, and weight the various components of the market basket differently.

Actually, a necessary condition for the absolute version of PPP to hold empirically is the validity of the law of one price. Isard (1977) studied the most desegregated grouping of manufactured goods for which prices are available for the period 1970-75. Isard (1977) found that the law of one price fails to hold. Even in commodities markets, where goods are more homogenous than in industrial goods markets, the law of one price is not valid in the short-run, though it tends to be so in the long-run. All these facts show the limitation of the strong, or absolute, version of PPP.

The weak, or relative, version of PPP does not require that exchange rates be equal to the ratio of price indices instantaneously. The exchange rate need 
only remain at some constant ratio. By incorporating transportation costs and other obstacles to trade in the concept of PPP, the relationship of exchange rates to relative prices between two countries can be written as:

$$
S_{t}=\phi\left(\frac{P_{t}}{P_{t}^{*}}\right)
$$

where $\phi$ is an arbitrary positive constant that reflects the existence of obstacles to trade or transportation costs. Taking logs and first differences, the equation can be written as:

$$
\Delta s_{t}=\Delta p_{t}-\Delta p_{t}^{*},
$$

where $\Delta$ denotes change and $s_{t}, p_{t}$ and $p_{t}^{*}$ are the logs of $S_{t}, P_{t}$ and $P_{t}^{*}$, respectively.

As a statement of the weak, or relative, version of PPP, equation (1.4) states that the percentage change in the exchange rate equals the percentage change in the relative price ratio between two countries. This relative version of PPP can also be interpreted as a requirement that the rate of inflation differential be equal to the rate of depreciation. The relative version of PPP, therefore, depends on the condition of the homogeneity postulate of money theory. The constancy of real variables under the assumption of money neutrality implies that once the economy has adjusted, changes in the exchange rate match changes in inflation. Baillie and McMahon (1993) have argued, however, that the hypothesis of money neutrality is not likely to hold true in the short run because of institutional rigidities and imperfect dissemination of information.

Both the absolute and relative versions of PPP can be expressed in terms of the real exchange rate, $r_{t}$, as follows:

$$
r_{t}=\frac{S_{t} P_{t}^{*}}{P_{t}}
$$

or

$$
R_{t}=s_{t}-\left(p_{t}-p_{t}^{*}\right),
$$

where $R_{t}$ is the log of the real exchange rate $\left(r_{t}\right)$.

This expression defines the real exchange rate in terms of purchasing power between two consumption baskets. It can be seen from (1.5) that the absolute version of PPP can be expressed as $r_{t}=1$ for all $t$, while in the case of the relative version of PPP, the real exchange rate is constant over time, that is, $R_{t+1}=R_{t}=R$. In addition, it is clear that the change in the real exchange rate could come from the change in the nominal exchange rate or from the change in the inflation differential.

\subsection{Deviations from Purchasing Power Parity}

The doctrine of PPP may be expressed as whether the level of exchange rate is characterized by a white noise process. That is, any deviation of the real exchange rate from its constant equilibrium level should be completely random. Therefore, if the real exchange rate behaves as suggested by PPP theory, any 
deviation of the actual real exchange rate from its PPP theory will reflect a transitory deviation from its long-run equilibrium.

Proponents of the doctrine of PPP hold vague and differing views about which particular ratio of price indexes should parallel the exchange rate. These views correspond to vague and different notions about the forces that act to correct purchasing power deviations. A monetarist school of thought, to which Cassel (1918) adhered, view the exchange rate to be held in line by general price indexes that summarize the price of both tradable and non-tradable goods and services: "People value currencies primarily for what they will buy and, in uncontrolled goods and services markets, tend to exchange them at rates that roughly express their relative purchasing powers" (Isard, 1987, p. 4). A second version of PPP views exchange rates to be held in line by cost-of-production indexes, arguing that competition and the international mobility of industry will prevent persistent purchasing power deviations. (Hansen, 1990). A third version of PPP, not inconsistent with the first two, focuses on commodity arbitrage through international trade as the mechanism that corrects purchasing power deviations: "The proposition that general price levels in different countries are connected through the prices of internationally traded goods is the foundation of the purchasing power parity doctrine" (Haberler, 1975, p. 24). Implicit in this third version is the additional proposition that relative prices of tradable and non-tradable remains approximately constant within countries.

A fourth version of PPP combines the following propositions: (a) the expected rate of change in the exchange rate between two currencies is approximately equal (assuming approximate risk neutrality) to the difference between the nominal rates of interest on assets denominated in the two currencies; (b) nominal interest rates equal real interest rates plus expected rate of domestic price inflation; and (c) real rates of interest tend to equality across countries. Jointly, these three propositions argue that the expected rate of change in the exchange rate is approximately equal to the differences between expected rates of domestic price inflation. This fourth version is further argued to suggest that observed rate of exchange rate change approximate difference between observed rates of domestic price inflation. Equivalently, observed rate of exchange-rate change are viewed to approximate observed rates of change in domestic price indexes.

Each of these four views has been challenged over the time. The last view is disputed by evidence that differences between nominal rates of interest have been highly inaccurate predictors of actual exchange-rate movements in recent years. Isard's (1987) statement of the monetarist view must bow to the fact that transportation and other transactions costs in reality leave room for substantial purchasing power deviations to occur before residents in any one country would find it economical to exchange an "overvalued" local currency for currencies to use in purchasing goods and services aboard. Similarly, advocates of the cost-parity view must recognize that ligh information and relocalization costs weaken the equilibrating forces sufficiently to permit substantial purchasing power deviations.

The third view of PPP, which states commodity arbitrage combined with constant relative prices of tradables and non-tradables, has been attacked on both counts. Cassel (1918) himself recognized that real changes in an econ- 
omy are likely to alter the relative prices of tradables and non-tradables, while Isard (1977) has attack the practical relevance of commodity arbitrage with empirical evidence that disputes "the law of one price" at the most desegregate level of product classification for which available price data can be readily matched across countries. Isard's evidence shows that, at this level of commodity detail, tradable goods manufactured by different countries behave like differentiated products that systematically exhibit large changes in their relative common-currency prices. Moreover, large relative-price disparities at this level of commodity detail can persist for at least several years. Thus, aggregate price indexes constructed from available data on tradable-goods price are also likely to be such that the ratio of price indexes for any pair of countries diverges substantially from the corresponding exchange rate for periods of at least several years.

From the discussion above, it is clear that there are several competitive interpretations of PPP. There are important differences across these views regarding the kind of corrective forces acting to restore the equilibrium between exchange rate and relative prices. These give rise to different hypothesis as to the nature of the PPP relationship, its validity and its relevance as a policy tool. From the discussion above, it is also clear that each interpretation is subject to criticisms that weaken the theoretical bases of PPP. Nevertheless, it is important to examine how well PPP stands up as an empirical proposition.

\subsection{Existing Empirical Tests of Purchasing Power Parity}

Most of the existing literature testing PPP has concentrated on countries within the OECD, mainly involving U.S., European and Japan currencies and relative prices. While a number of other studies focussing on data sets of countries outside this economic area, have dealt with high-inflationary economies. For example, McNown and Wallace (1989) test and find evidence for PPP in its absolute form for 4 high-inflation economies. Lui (1992) offers favorable evidence towards PPP for a number of Latin American countries; Conejo and Shields (1993) consider the role of the terms of trade in the case of 5 Latin American countries; and Mahdavi and Zhou (1994) re-examine PPP in a sample of 13 high-inflation in Latin American countries, using quarterly data over the modern float, and find evidence suggestive of PPP holding more strongly over periods where inflation is particularly rampant. Mahdavi and Zhou (1994)examines PPP for 4 high-inflation Less Developed Countries (LDCs) finding convincing support for PPP in the long-run.

Pérez-López (1995) examines the validity of the absolute version of PPP between the United States and Mexico, using the Engle and Granger and Stock and Watson co-integration methods. Computing the relative PPP based on the consumer price index (CPI) and wholesale price index (WPI) for the two countries, he finds evidence which casts severe doubt of PPP for these two countries for the period 1970-1994. De la Cruz (1994), testing the validity of the relative PPP based on both WPIs and CPIs, concludes that this version of PPP describes the behavior of peso/dollar during the fixed era; though he reject the stationary hypothesis of real exchange rate during the period of floating. To test for PPP, he applies the Granger and Engel co-integration method and a vector autoregression model. 
Given the renewed attention, it is surprising to note that very few studies have concentrated on the experience of LDCs in general. In the literature to date, Bahmani (1993) examined PPP using effective exchange rate for 25 LDCs finding much less than convincing support for exchange rate determination in long run. In an investigation of Singapore, Abeysinghe and Kok-Hong (1992) find evidence in favor of the relationship between its dollar and the U.S. dollar, though not with other currencies. Masih and Masih (1995), using a fractional co-integration approach, find evidence in favor of the relationship between Taiwan dollar and the U.S. dollar.

Gaol (1994) examines what has been refereed to as the Generalized-PPP theory, arguing that many of the empirical studies which support the random walk PPP hypothesis use a bilateral real exchange rate model while ignoring international interdependency. He suggests estimating PPP using a system estimation accounting for the correlation of error terms across countries and for serial correlation within countries. Real exchange rates for his study were computed based on an absolute version of PPP using CPIs for Indonesia, Malasya, Philippines, Thailand, and Singapore. The tests were conducted controlling for institutional changes, using the Perron (1989) unit root real exchange rate tests. His study fails to accept that PPP holds in several currencies simultaneously. Kim (1990) investigate the validity of PPP for the Pacific Rim economies over the fixed and flexible exchange rate cras. The tests were conducted controlling for institutional changes, using the Perron (1989) unit root real exchange rate tests. Kim cannot reject the null hypothesis that the real exchange rate has a unit root. Therefore, the PPP hypothesis does not hold in all the countries studied: South Korea, Philippines and Thailand.

Even with this mixed support of PPP in developed countries and relatively strong support of PPP in economies with relatively high inflation, there is no reason to expect that PPP may hold or may not hold, a priori, in less than fully industrialized countries. Moreover, one possibility in high-inflation countries, where PPP has not obtained much support, is that the existing studies have not modeled the variables appropriately, as some of them claim that the first differences of the exchange rate and price variables of high-inflation countries are nonstationary and their levels are integrated of order two.

Mexico is a representative of high-inflation countries and earned a reputation for his willingness to undertake liberal economic reforms during the $1980 \mathrm{~s}$. Mexican reforms for stabilization and market oriented trade and industrial policies crate a more outward-oriented economy. Moreover, important institutional changes have occurred during the last decade provide an interesting case to test PPP with structural changes. The Mexican government responded to the debt crisis of 1982 with a series of structural adjustment measures which continued throughout the decade. In 1985, stated a liberalization program and suffer an oil price shock. In 1988 began a comprehensive the stabilization program. In light of these institutional changes in a high inflation economy as Mexico, is necessary an empirical investigation on the validity of PPP in presence of structural breaks. 


\section{Tests of Purchasing Power Parity}

To test the PPP relationship in the Mexican economy we apply unit root test in the presence of structural change, following the methodology developed by Perron (1989). The econometric model using equation (1.1) is:

$$
S_{t} P_{t}^{*}-\varphi P_{t}=\varepsilon_{t}
$$

where $P_{t}$ is the domestic price level (Mexico's price level); $S_{t}$ is the nominal exchange rate defined as the price of a unit of foreign currency in terms of domestic currency (Mexican pesos per U.S. dollar); $P_{t}^{*}$ is the foreign price level (U.S. price level); and the subscript $t$ refers to time. According to equation (1.7), the long run hypothesis PPP holds if $P_{t}$ equals $S_{t} P_{t}^{*}$, which implies that $\varphi=1$ and $\varepsilon_{t}$ is stationary with a mean equal to zero. All $P_{t}, S_{t}$, and $P_{t}^{*}$ are endogenous variables that are jointly determined. This leads us to consider reformulating PPP in terms of the real exchange rate to preclude the possibility of using an instrument variable in estimating equation (1.7). Rearranging equation (1.7) gives:

$$
\frac{S_{t} P_{t}^{*}}{P_{t}}=\varphi+\zeta_{t}
$$

and

$$
r_{t}=\varphi+\zeta_{t}
$$

where $r_{t}$ is the real exchange rate and $\zeta_{t}$ is a stochastic disturbance that represents the deviations of the real exchange rate from its equilibrium value. In this form, long run PPP holds if $\zeta_{t}$ is stationary. $\varphi$ is a constant defined as the long run value of the real exchange rate.

Now, suppose that if $\zeta_{t}$ it is generated by a non-deterministic covariance stationary process. By the Wald decomposition theorem, $\zeta_{t}$ has a infinite order moving average representation that can be approximated by a finite autoregressive integrated moving average (ARIMA $(n, 0,0))$. The underlying process for the real exchange rate movement, therefore, is represented by:

$$
r_{t}=\beta_{0}+\beta_{1} r_{t-1}+\cdots+\beta_{n} r_{t-n}+\xi_{t}
$$

where $\xi_{t}$ is a serially uncorrelated stochastic disturbance with zero mean. Given this specification, the long run properties of PPP require that all characteristic roots of (1.9) lie within the unit circle.

This study tests whether real exchange rate follow stationary process. Consideration is given to the fact that using standard critical values based on normality distribution assumption is inappropriate for nonstationary variables. Dickey and Fuller $(1979,1981)$ introduced methodology for testing a unit root in the ARIMA representation and provided critical values for such tests in the case of nonstationary time series with multiple roots. The application of this test was improved when Said and Dickey (1984), proposed a generalization of the Dickey-Fuller procedure. Said and Dickey, however, yield test statistics with the same asymptotic critical values as those tabulated by Dickey and Fuller. This test statistic can be applied to models in which the orders of the ARIMA 
polynomials in the error process do not need to be identified. However, the procedure requires that error process is free of serial correlation. Phillips (1987) and Phillips and Perron (1988) have offered a more general procedure for testing a unit root in a time series model in which the restrictions on error process are such that serial correlation is relaxed.

Within the regression model framework, the change in one or more of the parameters indicates a structural break. Misspecification problems associated with a structural break have been related to unit root tests. The methods developed by Dickey and Fuller $(1979,1981)$, and Phillips and Perron (1988) are unable to detect such problems. As Perron (1989) has shown, a structural break may make an otherwise stationary variable appear to be a unit root process. In the presence of structural change, he has proposed a formal statistical test of the null hypothesis for the unit root in the spirit of "intervention analysis".

Perron (1989) considers three different alternatives for testing unit roots in the presence of regime shifts. The first regression is used to test unit roots in time-series models in the presence of a one-time jump in the mean of the process. The second tests the presence of a change in intercept. The third test in the presence of a one-jump on both the mean and the intercept of a unit root process. All three tests can be presented formally in terms of the exchange rate $\left(R_{t}\right)$.

Suppose there is a structural break in the Mexican economy at time $t=$ $i+1$. For the first test, consider the null hypothesis of a one-time change in the mean of a unit root process against the alternative hypothesis of a onetime jump in the intercept of a trend stationary process. Formally, the null hypothesis is:

$$
\mathrm{H}_{0}: R_{t}=\mu_{0}+R_{t-1}+\alpha_{0} D_{1}+\xi_{t}
$$

and

$$
\mathrm{H}_{1}: R_{t}=\mu_{1}+\beta t+\alpha_{a} X_{t}+\xi_{t}
$$

where $R_{t}$ is the log of the real exchange rate $\left(r_{t}\right) ; D_{1}$ is a dummy variable such that $D_{1}=1$ if $t=i+1$, and zero otherwise; $X_{t}$ is a dummy variable such that $X_{t}=1$ for $t>i$, and zero otherwise; and $\mu$ 's, $\beta$ 's , and $\alpha$ 's are parameters of the null and alternative hypothesis.

The second alternative considers the null hypothesis of a permanent shift in the drift mean against the alternative of a change in the slope of the trend. In this case, the null and alternative hypotheses are:

$$
\mathrm{H}_{0}: R_{t}=\mu_{0}+R_{t-1}+\mu_{1} D_{2}+\xi_{t}
$$

and

$$
\mathrm{H}_{1}: R_{t}=\mu_{a}+\beta_{1} t+\beta_{2} D_{3}+\xi_{t}
$$

where $D_{2}=1$ if $t>i$, and zero otherwise. Equation (1.11a) implies that the $\left\{R_{t}\right\}$ sequence is generated by $\Delta R_{t}=\mu_{0}+\xi_{t}$ up to period $t=i$, and by $\Delta R_{t}=\left(\mu_{0}+\mu_{1}\right)+\xi_{t}$ as $t>i . D_{3}=t-i$ if $t>i$, and zero otherwise. From equation $(1.11 b)$, the slope of the trend is $\beta_{1}$ for $t \leq i$ and $\left(\beta_{1}+\beta_{2}\right)$ for $t>i$.

The third alternative combines the two cases above. Formally, the null hypothesis and alternative hypothesis are:

$$
\mathrm{H}_{0}: R_{t}=\mu_{0}+R_{t-1}+\mu_{1} D_{1}+\mu_{1} D_{2}+\xi_{t}
$$


and

$$
\mathrm{H}_{1}: R_{t}=\mu_{a}+\beta_{1} t+\beta_{2} D_{3}+\alpha_{a} X_{t}+\xi_{t}
$$

where $D_{1}, D_{2}, D_{3}$ and $X_{t}$ are defined as above.

In pursing the test, the raw series $\left\{R_{t}\right\}$ is first detrended according to one of the alternatives, in first (I), second (II) and third (III). Let $\{\bar{R}\}, i=\mathrm{I}$,II,III, be the residuals from regression of $R_{t}$ as follows:

$$
\begin{aligned}
& \text { For } i=\mathrm{I}, R_{t}=\mu_{a}+\beta_{1} t+\alpha_{a} X_{t}+\bar{R}_{\bar{t}}, \\
& \text { For } i=\mathrm{II}, R_{t}=\mu_{a}+\beta_{1} t+\beta_{2} D_{3}+\bar{R}_{t}, \\
& \text { For } i=\mathrm{III}, R_{t}=\mu_{a}+\beta_{1} t+\beta_{2} D_{3}+\alpha_{a} X_{t}+\bar{R}_{t} .
\end{aligned}
$$

Thus, let $\hat{\alpha}^{i}$ be the least squares estimator of $\alpha^{i}$ in the following regression:

$$
R_{t}=\alpha^{i} \bar{R}_{t-1}^{i}+\bar{\varepsilon}_{t}, \quad i=\mathrm{I}, \mathrm{II}, \mathrm{III} \quad t=1,2, \cdots, T,
$$

where under the null hypothesis of a unit root, the theoretical value of $\alpha^{i}=1$. In the case that the residuals $\left(\bar{\varepsilon}_{t}\right)$ are identically and independently distributed, the limiting distribution of $t_{\alpha i}$ depends on the proportion of observations occurring prior the break, $\lambda=i / T$, where $T$ is the total number of observations. The critical values for alternatives, I, II, and III are presented in Perron (1989), Tables IV, V, and VI, respectively.

For the case that the residuals, $\bar{\varepsilon}_{t}$ are serially correlated, some modifications are necessary. Two approaches are possible. One is to follow the method suggested by Phillips (1987), and Phillips and Perron (1988). The other is to use the method suggested by Dickey and Fuller $(1979,1981)$. The latter approach includes the application of the ADF test. This framework was formed by the regression:

$$
\Delta R_{t}=\alpha^{i} \bar{R}_{t+1}^{i}+\Sigma \gamma_{i} \Delta \bar{R}_{t}+\bar{\varepsilon}_{t} t, \quad i=\mathrm{I}, \mathrm{II}, \mathrm{II},
$$

where $\Delta R_{t}=R_{t}-R_{t-1}$, and lag $k$ is sufficient large for $\varepsilon_{t}$ to be serially uncorrelated. The limiting distributions for $t_{\alpha i}$ in this case, then, are the same as when the errors are identically and independently distributed and regression (1.14) is used in the test.

\section{Data and Sources of Information}

Having presented the method to test for a unit root in the real exchange rate time-series data when there is a structural change within the sample period. We now turn in to measure the real exchange rate. There is a great deal of 
confusion in the literature regarding the appropriate definition of the real cxchange rate and the appropriate choice of the price indices. Theoretically there is no correct answer as to what index should be used; therefore, one can formulate different theories, and the appropriate index can vary with the theory.

Another problem regarding the definition of real exchange rate is the base year and the trade-weights used. By base year is meant that the year has to be stable to reflect technologic change, whereas by trade-weights is meant that the real exchange rate can be measured using trade-weights shares, major trading-weights, import-weights, tradable and non-tradable goods weights and gross domestic product. Recent empirical evidence suggests that depending on the base year and the weights used the real exchange rate indices denote real appreciation, real depreciation, and a real exchange rate in equilibrium.

In an effort to minimize measurement problems, twelve different measures of real exchange rate (RER) are used in this paper. First, the traditional definition is the nominal exchange rate times the relative prices at home and abroad.

RER1: Bilateral real exchange rate computed as nominal exchange rate deflated by the consumer price index Mexico-U.S. The reference base year is, $1970=100$. Source: IMF, $P_{t}=$ line $64 ; P_{t}^{*}=$ line 64 ; and $S_{t}=$ line rf.

RER2: Bilateral real exchange rate computed as nominal exchange rate deflated by the consumer price index Mexico-U.S. The reference base year is, $1992=100$. Source: same as above.

Second, a modification of the traditional definition is the effective real exchange rate which is defined as a weighted average of foreign prices to domestic price level.

RER3: Multilateral real exchange rate computed as nominal effective exchange rate deflated by the consumer price index of Mexico's 20 major trading partners. ${ }^{1}$ The weights assigned to the multilateral exchange rates (Mexican peso per unit of foreign currency) are based on the bilateral trade-share of Mexico's 20 major trading nations with the reference base year, $1992=100$. These countries account for $82 \%$ of Mexican total exports in 1992. Source: Banco de México. Indicadores Econónicos.

RER4: Multilateral real exchange rate computed as nominal effective exchange rate deflated by the consumer price index of Mexico's 20 major trading partners. The weights assigned to the multilateral exchange rates (Mexican peso per unit of foreign currency) are based on Mexico's gross domestic product in relation to 20 major trading partners with the reference base year, $1992=100$. Source: same as above.

Third, a modern definition that has been quite popular in recent years regards the real exchange rate as being the ratio of the price of tradable to non-tradable goods. ${ }^{2}$

1 The effective exchange rate has become more useful for a behavioral analysis of exchange rate management, especially during the presence of loating (managed or not) exchange rate regimes under which the behavior of the external value of a currency is difficult to ascertain.

2 Harberger(1986), however, has argued against this definition. He suggests that from analytical perspective, the most useful definition of the real exchange rate is the nominal 
RER5: Bilateral U.S.-Mexico real exchange rate computed as nominal exchange rate deflated by the ratio of tradable to non-tradable price index. The reference base year is $1980=100$. Source: Banco de México. Índices de Precios.

RER6: Bilateral U.S.-Mexico real exchange rate computed as the above. The reference base year is $1992=100$. Source: same as above.

Fourth, a different definition of real exchange rate includes the unitary labor cost (direct and indirect) and their productivity in different countries. The deifnition also includes the nominal exchange rate deflated by the ratio of tradable to nontradable price index. ${ }^{3}$

RER7: Multilateral labor unit cost real exchange rate is computed as the ratio of the unitary labor cost of the major countries partners and Mexico's unit labor costs. The weights assigned to the unit wage cost RER are based on Mexico's 8 major trading partners with the reference base year, $1980=100$. The weights are as follows: United States (0.48), Japan (0.33), Germany (0.06), Canada (0.05), United Kingdom (0.04), France (0.02), Italy (0.1), and Spain (0.01). Source: Banco de México. Indicadores Económicos.

RER8: Multilateral labor unit cost real exchange rate is computed as the ratio of the unitary labor cost of the major countries partners and Mexico's unit labor costs. The weights assigned to the multilateral labor unit cost RER are based on Mexico's 8 major trading partners with the reference base year, 1992=100. Source: Banco de México. Indicadores Económicos.

RER9: Multilateral wage ratio real exchange rate same as the above except unit labor cost are adjusted by productivity and the weights are based on trade. The reference year is $1992=100{ }^{4}$ Source: Banco de México. Indicadores Económicos.

RER10: Same as the above except the weights are based on gross national product of Mexico's 20 major partners. The reference year is $1992=100$. Source: Banco de México. Indicadores Económicos.

A fifth criteria to measure the real exchange rate commonly utilized in the literature, is the ratio of the interest rate using a weighted by trade or GDP.

RER11: Multilateral interest rate real exchange rate computed as the ratio of the interest rate and the weights are based on trade. The reference year is 1992=100. Source: Banco de México. Indicadores Económicos.

exchange rate deflated by a theoretical general price index. However, this is a novel proposition, since it does not correspond to any of the more common definition used in the literature. From practical point of view, moreover, it is not easy to find the appropriate general price index. After discussing a number of alternatives, Harberger concludes that, given availability and periodicity, the consumer price index is the best real-world counterpart to the ideal theoretical price index.

3 The RER $=S_{t}\left(W^{*} / W^{m}\right)$, where $W$ is total remuneration per hour, $S_{t}$ in nominal exchange rate and the index ${ }^{*}$ and $m$ correspond to Mexico and the rest of the world, respectively.

4 The RER $\left.=\left[(W / Q)^{*} /(W / Q)^{m}\right)\right]$, where $W$ is wage per hour, $Q$ is production/worker per hour, the index * and $m$ correspond to Mexico and the rest of the world, respectively. 
RER12: Multilateral interest rate real exchange rate computed as the ratio of the interest rate and the weights are based on GDP. The reference year is $1992=100$. Source: Banco de México. Indicadores Económicos.

One can of course generate even more versions of the real exchange rate by changing the price index utilized. In selecting the appropriate price measure, three alternative are commonly used: Wholesale Price Index (WPI), the Consumer Price Index (CPI), and the GDP deflator. Concerning these alternatives, several points may be noted. As remarked by Officer (1980), the use of WPI biases the analysis in favor of PPP because, in concept, WPI is heavily weighted with tradable goods. Thus, to be anything much more than a truism, the index chosen should be reasonably broadly based. This suggests the use of the GDP deflator, which covers both tradable and nontraded goods, and investment as well as consumption goods.

However, as also noted by Officer (1980), there is a serious limitation with the GDP deflator; it is a current-weighted index rather than a base-weighted index, as is the case of the CPI. Therefore, the GDP deflator will not purely reflect average price level changes. This suggest the CPI might be a reasonable practical choice because, although it covers only consumption goods, it does cover both traded and nontraded goods sectors and also has the advantage of being a base-weighted index expressly designed to measure changes in the price level of an average basket of commodities consumed by members of an economy. Therefore, CPI is the selected price measure for this analysis.

Figures 1.1-1.8 show the behavior of the real exchange rate for each definition, during the period 1980:1 to 1997:1. As might be observed, the figures show no clear tendency towards long run exchange rate appreciation. To avoid hasty conclusions, and in order to analyze the behavior of real exchange rate we estimate the unit root test in the next section.

Figure 1.1 Real Exchange Rate: Nominal Exchange Rate. Deflated by Consumer Price Index.

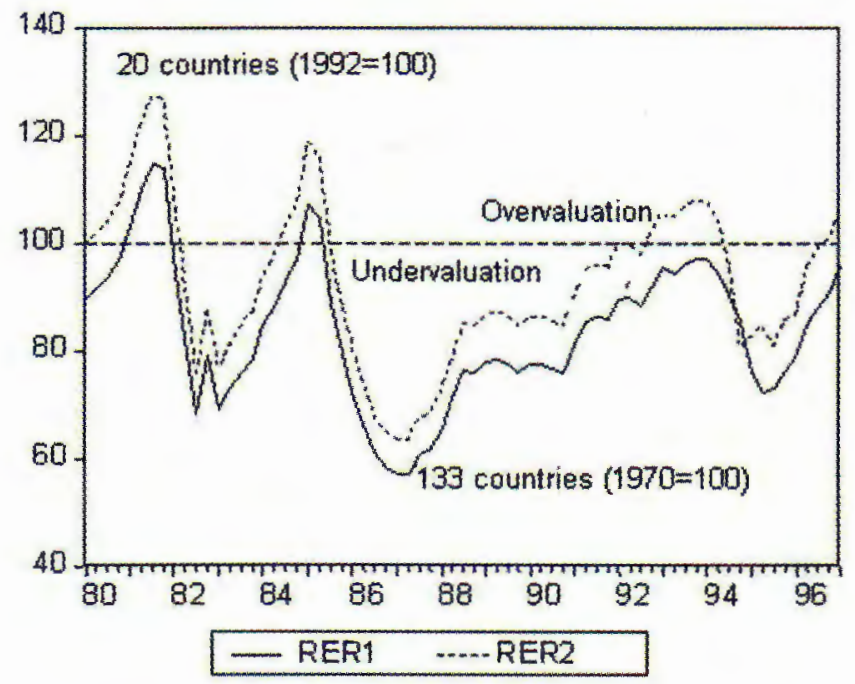


Figure 1.2 Real Exchange Rate: Nominal Efective Exchange. Deflated by Consumer Price Index, Mexico's 20 Trading Partners (GDP Weights).

Price Index: $1992=100$.

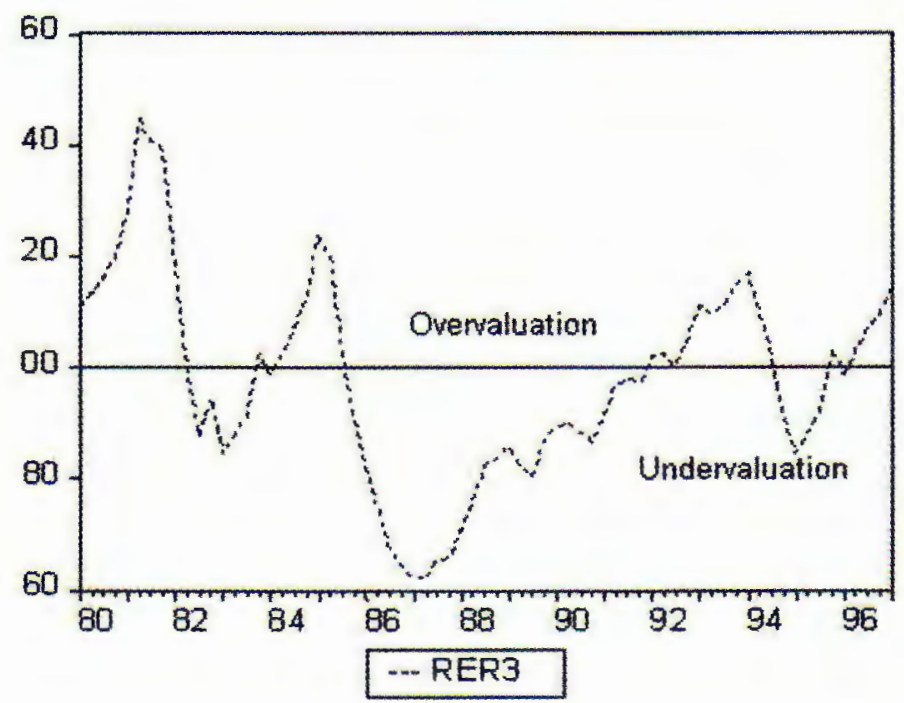

Figure 1.3 Real Exchange Rate: Nominal Exchange Rate. Deflated by the Ratio of Tradable to Non-Tradable.

Price Index: 1980=100.

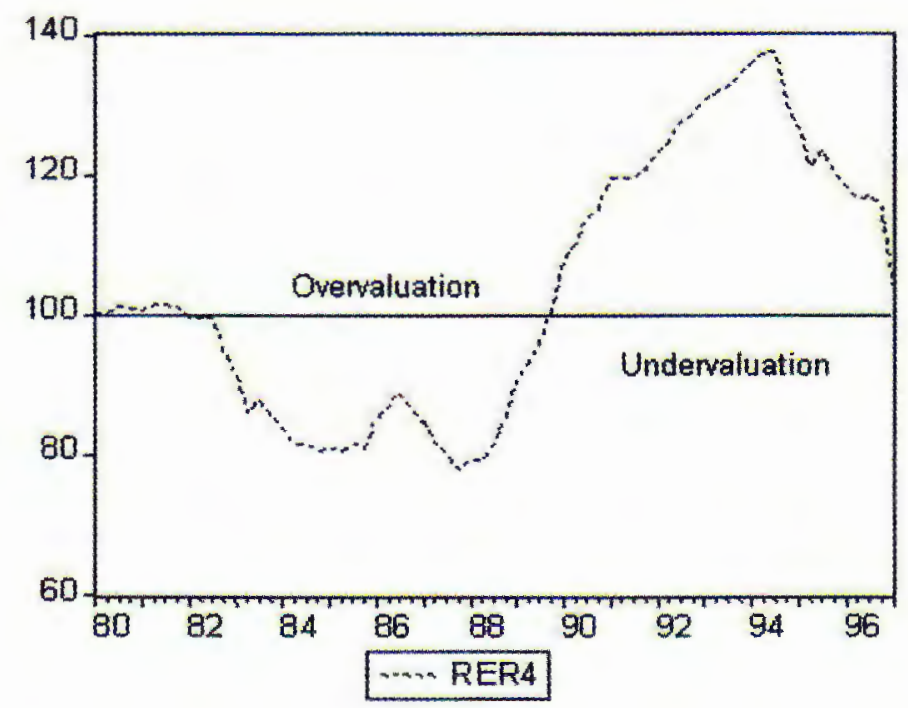


Figure 1.4 Real Exchange Rate: Nominal Exchange Rate. Deflated by the Ratio of Tradable to Non-Tradable.

Price Index: $1992=100$.

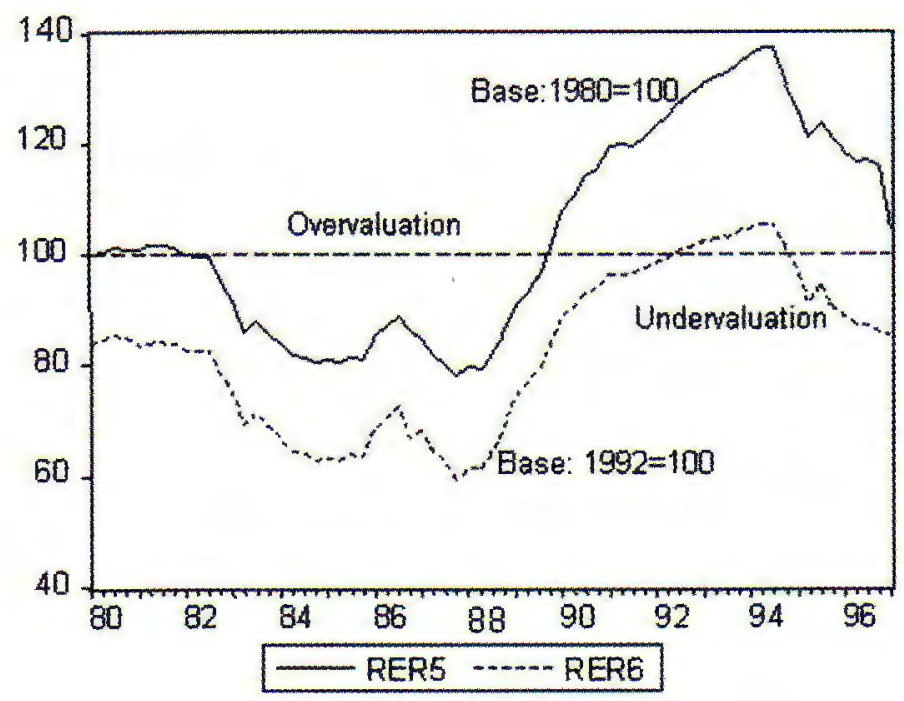

Figure 1.5 Real Exchange Rate: Manufacturing Unitary Labor Cost. Price Index: $1980=100$

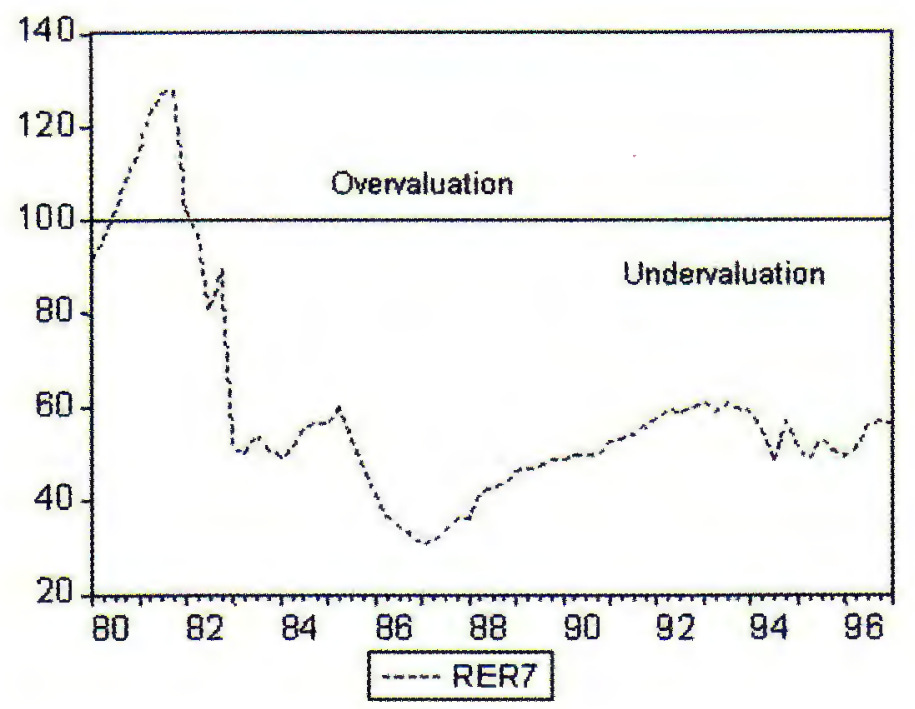


Figure 1.6 Real Exchange Rate: Unit Labor Costs in the Manufacturing Industry and Ratio of Wages Ajusted by Productivity, for Mexico's 8 Major Partners (GDP Weighted).

Price Index: $1992=100$.

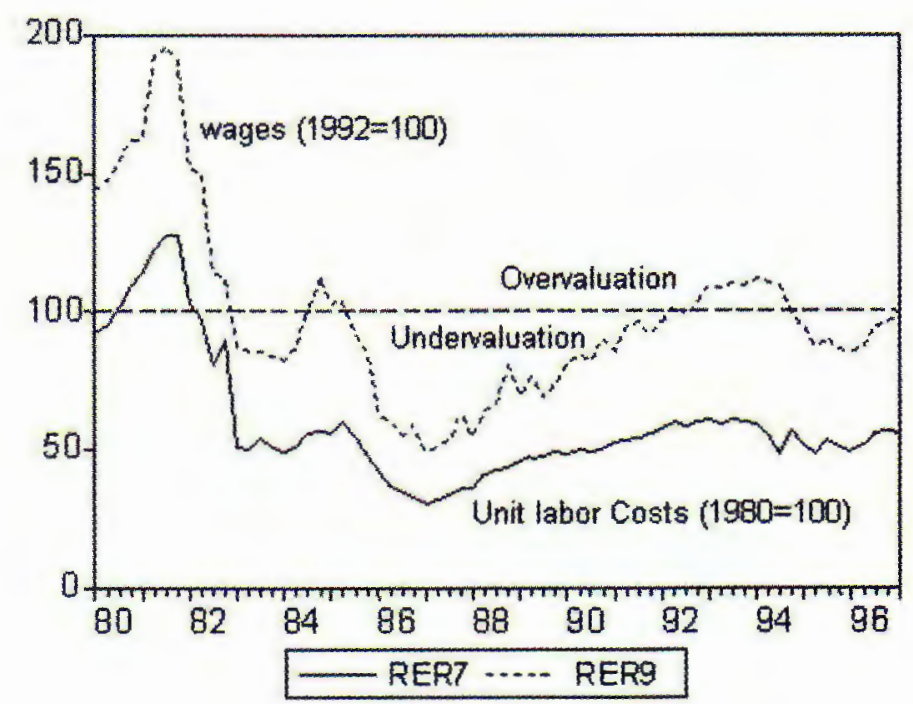

Figure 1.7 Real Exchange Rate: Manufacturing Unitary Labor Cost. Price Index: $1992=100$.

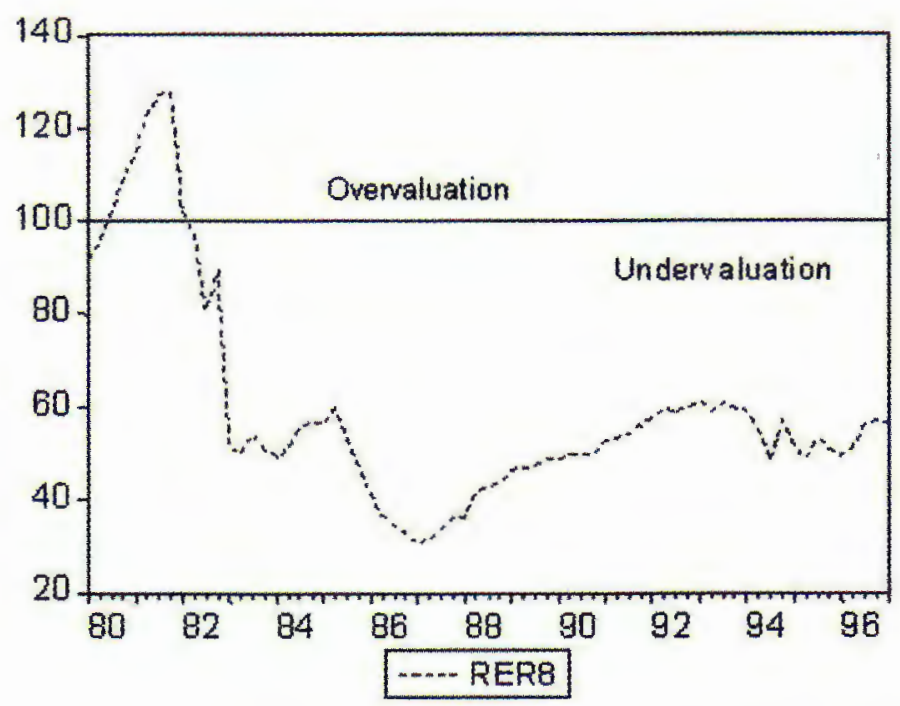


Figure 1.8 Real Exchange Rate: Unit Labor Costs in the Manufacturing Industry and Ratio of Wages Ajusted by Productivity, for Mexico's 8 Major Partners (Trade Weighted).

Price Index: $1980=100$.

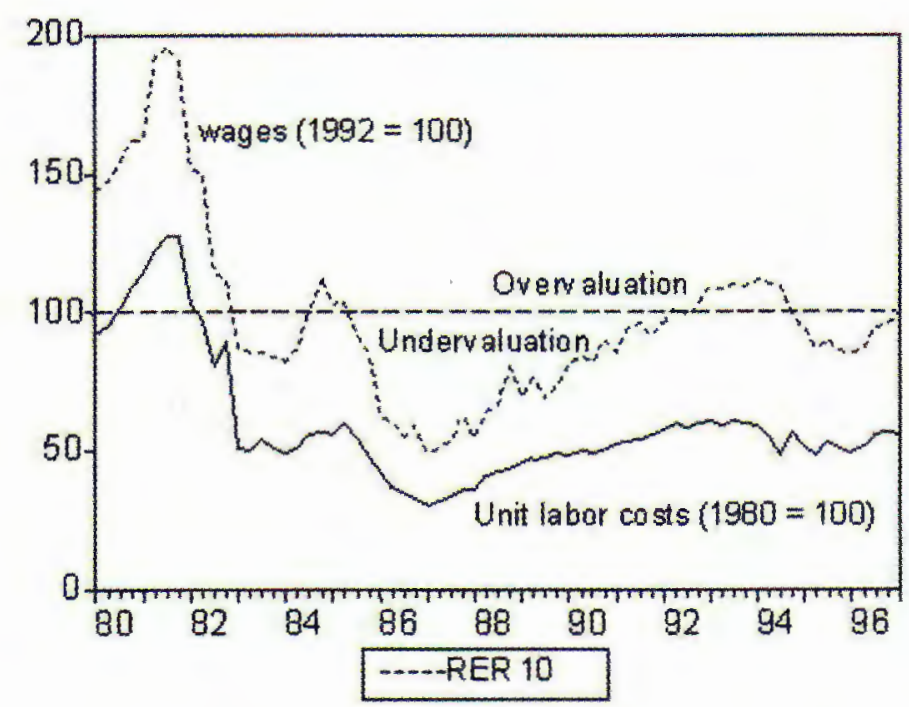

Figure 1.9 Real Exchange Rate with Interest Rates of Mexico's 20 Major Trade Partners (GDP Weights).

Price Index: $1980=100$.

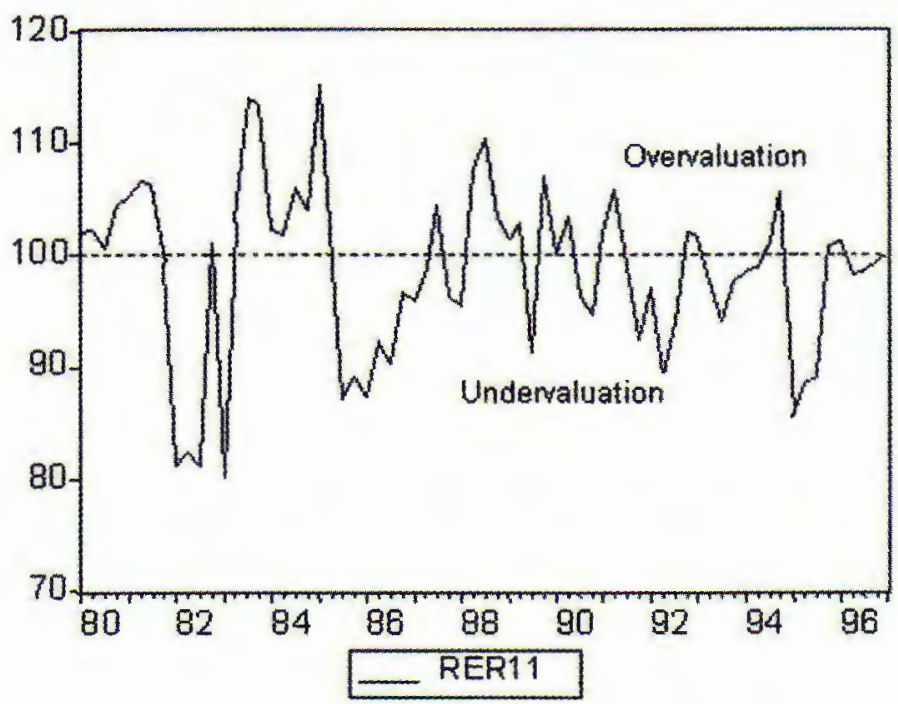


Figure 1.10 Real Exchange Rate with Interest Rates of Mexico's 20 Major Trade Partners.

Price Index: $1992=100$.

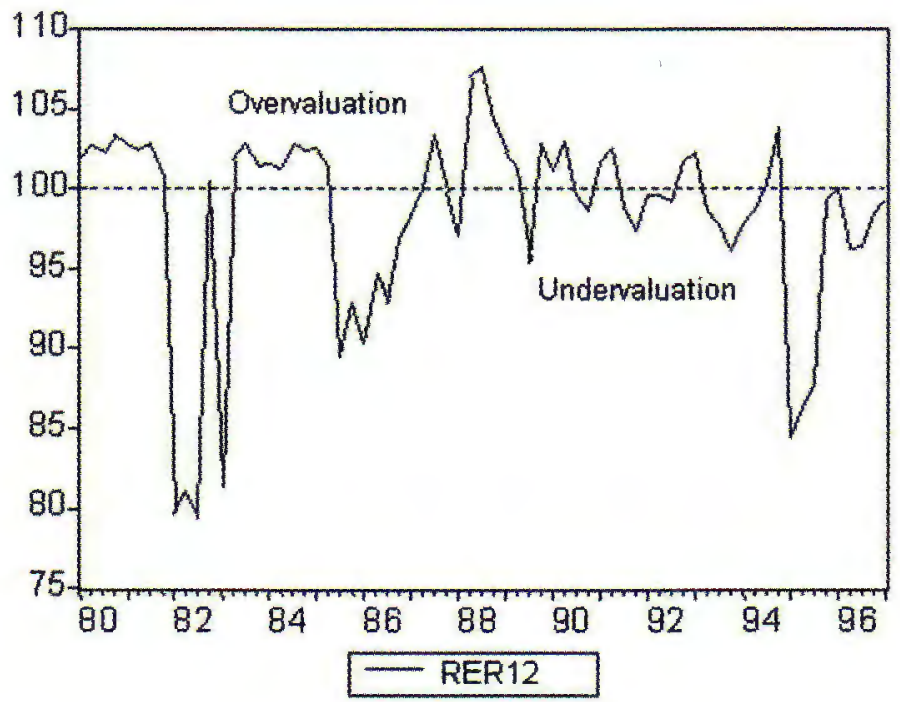

\section{Empirical results}

In this section the result of testing for stationarity of the real exchange rate are reported. In this specification of PPP, equation (1.1), the real exchange rate is defined in twelve different ways. These different definitions correspond to different notions about the forces that act to correct purchasing power parity.

The empirical investigation is conducted by testing PPP using Perron (1989) method, which accommodates a one-time structural break.. These correspond to the Mexican debt crisis in September 1982, the decline of the oil prices in June 1985 and the integral stabilization program of March 1987. To account for these structural changes, the unit root tests were estimated using three points of structural breaks; the first, was set on September $1982\left(T_{B}=\right.$ 1982:II); the second, was on December $1985\left(T_{B}=1985:\right.$ IV $)$; and the third, was set on March 1988 ( $\left.T_{B}=1988: \mathrm{I}\right)$. In each structural change the Mexican economy started with the change in Mexico's exchange rate system that accompanied with the adjustment of the rate. This condition justifies the choice of the third alternative test of Perron (1989) in investigating the validity of PPP in this study. An augmented Dickey-Fuller test was used with the detrended the series. A lag of two was chosen for all the tests ensuring that disturbances are serially uncorrelated.

In Tables 1.1 through 1.3, the structural unit root tests of the real exchange rates are reported. 
Tabla 1.1 Unit Roots Tests with Structural Break Second Quarter 1982*

\begin{tabular}{|c|c|c|c|c|c|c|}
\hline$X_{t}^{a}$ & $\mu_{a}$ & $\beta_{1}$ & $\beta_{2}$ & $\overline{\beta_{3}}$ & $\alpha_{a}$ & $\bar{\alpha}_{A}^{b}$ \\
\hline \multirow[t]{2}{*}{ RER1 } & 12.94 & 22.42 & -1.14 & -0.79 & 0.59 & 0.83 \\
\hline & $(0.61)$ & $(4.84)$ & $(-0.06)$ & $(-0.23)$ & $(0.26)$ & (13.30) \\
\hline \multirow[t]{2}{*}{ RER2 } & 22.33 & 23.89 & -7.56 & -1.24 & 1.29 & 0.81 \\
\hline & $(0.86)$ & $(4.25)$ & $(-0.32)$ & $(-0.50)$ & $(0.52)$ & (11.74) \\
\hline \multirow[t]{2}{*}{ RER3 } & 8.75 & 16.04 & 2.16 & 0.15 & -0.05 & 0.85 \\
\hline & $(0.29)$ & $(2.30)$ & $(0.09)$ & $(0.06)$ & $(-0.03)$ & (13.78) \\
\hline \multirow[t]{2}{*}{ RER4 } & 23.20 & 14.03 & -12.60 & -1.51 & 1.57 & 0.84 \\
\hline & $(0.96)$ & $(2.47)$ & $(-0.54)$ & $(0.64)$ & $(0.67)$ & $(13.59)$ \\
\hline \multirow[t]{2}{*}{ RER5 } & -1.19 & -5.18 & 3.57 & 0.32 & -0.33 & 0.87 \\
\hline & $(-0.11)$ & $(-1.88)$ & $(0.32)$ & $(0.29)$ & $(0.30)$ & $(27.26)$ \\
\hline \multirow[t]{2}{*}{ RER6 } & 3.85 & -2.89 & 0.23 & 0.20 & -0.16 & 0.93 \\
\hline & $(-0.39)$ & $(-1.22)$ & $(0.03)$ & $(0.21)$ & $(-0.16)$ & $(25.31)$ \\
\hline \multirow[t]{2}{*}{ RER7 } & 66.82 & 13.74 & -56.81 & -4.82 & 4.83 & 0.71 \\
\hline & $(2.52)$ & $(5.60)$ & $(-2.25)$ & $(-1.92)$ & $(1.96)$ & $(11.27)$ \\
\hline \multirow[t]{2}{*}{ RER8 } & 125.75 & 50.93 & -106.80 & -8.92 & 9.11 & 0.68 \\
\hline & $(2.65)$ & (4.73) & $(-2.36)$ & $(-1.99)$ & $(2.03)$ & (10.13) \\
\hline \multirow[t]{2}{*}{ RER9 } & 22.77 & 10.51 & -16.10 & -2.23 & 2.33 & 0.87 \\
\hline & $(0.50)$ & (1.03) & $(-0.37)$ & $(-0.50)$ & $(0.52)$ & $(15.30)$ \\
\hline \multirow[t]{2}{*}{ RER10 } & 15.45 & 3.91 & -8.73 & -1.73 & 1.77 & 0.89 \\
\hline & $(0.41)$ & $(0.45)$ & $(-0.23)$ & $(-0.46)$ & $(0.46)$ & $(15.60)$ \\
\hline \multirow[t]{2}{*}{ RER11 } & 106.39 & 7.45 & -10.64 & -2.39 & 2.26 & 0.05 \\
\hline & $(2.33)$ & $(0.94)$ & $(-0.33)$ & $(-0.68)$ & $(0.66)$ & $(0.18)$ \\
\hline \multirow[t]{2}{*}{ RER12 } & 80.62 & 9.52 & -14.32 & -2.69 & 2.68 & 0.36 \\
\hline & $(2.16)$ & $(1.45)$ & $(-0.57)$ & $(-1.00)$ & $(0.99)$ & $(1.59)$ \\
\hline
\end{tabular}

a Data are quarterly averages of monthly observations from the first quarter of 1980 to the first quarter of 1997 . The sample consists of 67 observation to estimate.

${ }^{b}$ Under the null hypothesis $\mathrm{H}_{0}: \bar{\alpha}_{A}=1$, the critical values at $10 \%, 5 \%$ and $1 \%$ are $-3.95,-4.24$, and -4.88 respectively, Perron (1989, p.1377, Table VI.B). The time of the break relative to total sample size $\lambda=12 / 67=0.179$. The structural change analyzed was the third quarter of 1982 .

* Here we only consider the model c (equations 1.13a to 1.13c), which involves estimating the following regression equation:

$$
R_{t}=\mu_{a}+\beta_{1} D_{1}+\beta_{2} D_{3}+\beta_{3} t+\alpha_{a} X_{t}+\alpha_{A} \bar{R}_{t-1}+\Sigma \gamma_{i} \Delta \vec{R}_{t-i}+\varepsilon_{x t}
$$

where the dummy variables are defined as above. 
Tabla 1.2 Unit Roots Tests with Structural Break Fourth Quarter 1985*

\begin{tabular}{ccccccc}
\hline$X_{t}^{a}$ & $\mu_{a}$ & $\beta_{1}$ & $\beta_{2}$ & $\beta_{3}$ & $\alpha_{a}$ & $\bar{\alpha}_{A}^{b}$ \\
\hline RER1 & 33.97 & 3.75 & -12.31 & -0.002 & 0.22 & 0.60 \\
& $(3.23)$ & $(0.67)$ & $(-1.96)$ & $(-0.00)$ & $(0.83)$ & $(6.17)$ \\
RER2 & 39.75 & 3.94 & -13.9 & -0.002 & 0.24 & 0.58 \\
& $(3.36)$ & $(0.61)$ & $(-1.90)$ & $(-0.00)$ & $(0.70)$ & $(5.66)$ \\
RER3 & 47.17 & 6.16 & -25.76 & -0.24 & 0.61 & 0.58 \\
& $(3.81)$ & $(0.96)$ & $(-3.06)$ & $(-0.82)$ & $(1.85)$ & $(6.38)$ \\
RER4 & 25.92 & -0.37 & -10.62 & -0.19 & 0.37 & 0.73 \\
& $(2.37)$ & $(-0.07)$ & $(-1.42)$ & $(-0.66)$ & $(1.09)$ & $(8.91)$ \\
RER5 & -4.97 & 2.36 & 6.28 & 0.10 & -0.19 & 1.03 \\
& $(-0.76)$ & $(-0.88)$ & $(1.24)$ & $(0.69)$ & $(-101)$ & $(18.46)$ \\
RER6 & 4.65 & 3.81 & -1.07 & 0.02 & -0.06 & 0.94 \\
& $(0.87)$ & $(1.65)$ & $(-0.26)$ & $(-0.13)$ & $(0.37)$ & $(17.78)$ \\
RER7 & 78.02 & 0.07 & -59.77 & -1.99 & 2.31 & 0.34 \\
& $(3.61)$ & $(0.01)$ & $(-3.34)$ & $(-3.02)$ & $(3.22)$ & $(2.32)$ \\
RER8 & 130.78 & 0.37 & -99.49 & -3.36 & 3.85 & 0.35 \\
& $(3.51)$ & $(0.04)$ & $-3.24)$ & $(-2.97)$ & $(3.31)$ & $(2.37)$ \\
RER9 & 49.47 & -7.61 & -35.44 & -0.85 & 1.20 & 0.65 \\
& $(2.33)$ & $(-1.01)$ & $(-1.96)$ & $(-1.50)$ & $(1.69)$ & $(6.58)$ \\
RER10 & 12.65 & -8.55 & -2.42 & -0.02 & 0.17 & 0.82 \\
& $(0.82)$ & $(1.45)$ & $(-0.18)$ & $(-0.03)$ & $(0.11)$ & $(10.12)$ \\
RER11 & 102.97 & -9.12 & 13.54 & 0.68 & 0.73 & -0.16 \\
& $(4.07)$ & $(-1.12)$ & $(1.78)$ & $(1.78)$ & $(1.87)$ & $(0.60)$ \\
RER12 & 80.62 & 9.52 & -14.32 & -2.69 & 2.68 & 0.36 \\
& $(2.16)$ & $(1.45)$ & $(-0.57)$ & $(-1.00)$ & $(0.99)$ & $(1.59)$ \\
\hline
\end{tabular}

a Data are quarterly averages of monthly observations from the first quarter of 1980 to the first quarter of 1997 . The sample consists of 67 observations to estimate.

$b$ Under the null hypothesis $\mathrm{H}_{0}: \bar{\alpha}_{A}=1$, the critical values at $10 \%, 5 \%$ and $1 \%$ are $-3.95,-4.24$, and -4.88 respectively, Perron $(1989$, p. 1377 , Table VI.B). The time of the break relative to total sample size $\lambda=24 / 67=0.358$. The structural change analyzed was the second quarter of 1985 .

* Here we only consider the model c (equations $1.13 \mathrm{a}$ to $1.13 \mathrm{c}$ ), which involves estimating the following regression equation:

$$
R_{t}=\mu_{a}+\beta_{1} D_{1}+\beta_{2} D_{3}+\beta_{3} t+\alpha_{a} X_{t}+\alpha_{A} \bar{R}_{t-1}+\Sigma \gamma_{i} \Delta \bar{R}_{t-i}+\varepsilon_{x t}
$$

where the dummy variables are defined as follows. 
Tabla 1.3 Unit Roots Tests with Structural Break First Quarter 1988*

\begin{tabular}{ccccccc}
\hline$X_{t}^{a}$ & $\mu_{a}$ & $\beta_{1}$ & $\beta_{2}$ & $\beta_{3}$ & $\alpha_{a}$ & $\bar{\alpha}_{A}^{b}$ \\
\hline RER1 & 40.30 & -4.40 & -16.80 & -0.29 & 0.53 & 0.58 \\
& $(3.36)$ & $(-0.89)$ & $(-2.06)$ & $(-1.77)$ & $(2.29)$ & $(5.06)$ \\
RER2 & 46.60 & -5.05 & -18.50 & -0.35 & 0.59 & 0.56 \\
& $(3.36)$ & $(-0.86)$ & $(-2.08)$ & $(-1.76)$ & $(2.23)$ & $(4.75)$ \\
RER3 & 60.60 & -4.65 & -36.70 & -0.69 & 1.15 & 0.51 \\
& $(3.98)$ & $(-0.81)$ & $(-3.22)$ & $(-2.96)$ & $(3.38)$ & $(4.63)$ \\
RER4 & 26.93 & -4.55 & -7.51 & -0.28 & 0.37 & 0.73 \\
& $(2.62)$ & $(-0.90)$ & $(-1.03)$ & $(1.47)$ & $(1.55)$ & $(8.84)$ \\
RER5 & -9.12 & -3.67 & 15.00 & 0.10 & -0.37 & 1.07 \\
& $(-1.46)$ & $(-1.39)$ & $(2.96)$ & $(1.09)$ & $(-2.22)$ & $(19.50)$ \\
RER6 & 6.06 & -2.05 & 2.72 & -0.06 & 0.03 & 0.92 \\
& $(1.19)$ & $(-0.78)$ & $(0.67)$ & $(-0.76)$ & $(0.26)$ & $(17.84)$ \\
RER7 & 51.96 & -1.71 & -34.98 & -1.18 & 1.38 & 0.51 \\
& $(2.86)$ & $(-0.31)$ & $(-2.30)$ & $(-2.54)$ & $(3.76)$ & $(3.75)$ \\
RER8 & 89.09 & -3.34 & -59.10 & -2.04 & 2.35 & 0.50 \\
& $(2.86)$ & $(-0.35)$ & $(-2.29)$ & $(-2.54)$ & $(2.55)$ & $(3.72)$ \\
RER9 & 51.60 & 0.32 & -35.44 & -1.03 & 1.36 & 0.65 \\
& $(2.38)$ & $(0.04)$ & $(-1.80)$ & $(-2.00)$ & $(2.08)$ & $(5.98)$ \\
RER10 & 11.80 & 2.00 & 2.94 & -0.11 & 0.07 & 0.83 \\
& $(0.93)$ & $(0.29)$ & $(0.26)$ & $(-0.36)$ & $(0.22)$ & $(11.07)$ \\
RER11 & 112.53 & -11.60 & 12.63 & 0.13 & -0.31 & -0.18 \\
RER12 & $(413)$ & $(-1.47)$ & $(1.74)$ & $(0.59)$ & $(-1.28)$ & $(-0.66)$ \\
& 111.81 & -7.76 & 21.26 & 0.28 & -0.53 & -0.22 \\
& $(4.56)$ & $(-1.31)$ & $(3.39)$ & $(1.74)$ & $(-2.79)$ & $(-0.86)$ \\
\hline
\end{tabular}

a Data are quarterly averages of monthly observations from the first quarter of 1980 to the first quarter of 1997 . The sample consists of 67 observations to estimate.

${ }^{b}$ Under the null hypothesis $\mathrm{H}_{0}: \bar{\alpha}_{A}=1$, the critical values at $10 \%, 5 \%$ and $1 \%$ are $-3.95,-4.24$, and -4.88 respectively, Perron $(1989$, p. 1377 , Table VI.B). The time of the break relative to total sample size $\lambda=31 / 67=0.463$. The structural change analyzed was the third quarter of 1987.

* Here we only consider the model c (equations 1.13a to 1.13c), which involves estimating the following regression equation:

$$
R_{t}=\mu_{a}+\beta_{1} D_{1}+\beta_{2} D_{3}+\beta_{3} t+\alpha_{a} X_{t}+\alpha_{A} \bar{R}_{t-1}+\Sigma \gamma_{i} \Delta \bar{R}_{t-i}+\varepsilon_{z i t}
$$

where the dummy variables are defined as above.

The results of Table 1.1 suggest that, without exception, all the time series studied contains unit roots in their levels. Therefore, the Perron (1989) test supports the same results of nonstationarity of the real exchange rate. In other words, if $\alpha=1$, then the null hypothesis states that the series $\alpha t_{i}$ contains a unit root, or $\alpha t_{i}$ is nonstationary. 
The results of Table 1.2 and 1.3. suggest that, with exception of RER7 and RER8, all the time series contains unit roots in their levels. Using a multilateral labor unit cost real exchange rate, the Perron (1989) test supports stationarity. In other words, since we reject $H_{0}: \alpha=1$, then the null hypothesis states that the series $\varepsilon_{t}$ do not contains a unit root, or $\varepsilon$ stationary.

The discussion of whether PPP holds, then, has drifted on the empirical content and interpretation of the definition of the real excnange rate. The RER7 and RER8 definitions are the only ones that deserves scme serious consideration, since it is the one related to the competitiveness of $\mathrm{t}$.าe economy and the only one left out of most recent discussions of whether PPP holds.

In an open economy, the one factor of production whose cost may become misaligned with the rest of the world is labor. Credit may be costlier in a developing country but its higher cost cannot be compensated by moving the Real Exchange Rate. Technology can be readily assimilated from whatever source, specially embodied as foreign investment. The same can be said of entrepreneurial and organizational talent. But the domestic cost of labor can get out of line. It can do so because of any of an array of several possibilities, such as increased unionization, increased union aggressiveness, false business-laborwage-contracting which anticipated higher than realized inflation, backward wage-price indexation, etc. Therefore, in an open economy environment in which firms can hire or purchase the best capital equipment, technology and inputs available worldwide, the relevant cost to compare is the cost of labor. It does not make sense to consider the relative cost of house rents, or more generally the ratio of non-tradable prices to the prices of tradable, or the trend of several possible measurements of general price index. Firms do not pay tuitions, nor household rents. They pay for labor and other inputs and the use of other measurements of the trend in relative competitiveness is warranted (but misleading) only when information is unavailable to compare unitary labor costs. The results from these two series are supportive that purchasing power parity holds as a longrun concept for the Mexican peso during the floating rate period.

\section{Conclusion}

In this paper Perron's (1989) method of unit root was used to test whether PPP held between Mexico and its major partners, and among the members of the OECD. The unit root tests were estimated using three points of structural breaks; the first, was set on September $1982\left(T_{B}=1982:\right.$ II $)$; the second, was set on December $1985\left(T_{B}=1985: \mathrm{IV}\right)$; and the third, was set on March 1988 $\left(T_{B}=1988: \mathrm{I}\right)$. By way of testing for unit root of the real exchange rate, the null hypothesis of nonstationarity (e.g. PPP did not hold) was rejected for the case of real exchange rate based on the cost of production indices. The null hypothesis of nonstationarity was accepted for the real exchange rate based on relative prices of tradables and nontradables, for the real exchange rate based on the difference between the nominal rates of interest on assets denominated in the two currencies, and for the real exchange rate based on consumer prices indices.

One possible explanation for the pervasive finding is that these are timevaring real factors that are omitted from the PPP relationship. Stockman 
(1987) and Neary (1988) provide insight into the real factors, and Flynn and Boucher (1993) examine their effects on PPP. Another possible explanation is that Perron's methodology account for multiple structural breaks. A Markov switching process, like that in Engel and Hamilto(1990), could also be used to test robustness of our results. Finally, the discussion of whether PPP holds drifted on the empirical content and interpretation of the definition of the real exchange rate.

\section{Appendix}

\section{Definitions of real exchange rate}

The following data set correspond to the data utilized which were taken from the International Financial Statistics, International Monetary Fund, and Banco de México (various issues). The definitions of the time series included are as follows.

RER1 = Bilateral real exchange rate computed as nominal exchange rate deflated by the consumer price index Mexico-U.S. 1970=100.

RER2 $=$ Same as the above, except the reference base year is $1992=100$.

RER3= Multilateral real exchange computed as nominal effective exchange rate deflated by the consumer price index of Mexico's 20 major trading partners. The weights are based on the bilateral trade-share of Mexico's 20 major trading nations. $1992=100$.

RER4= Same as the above, except the weights are based on Mexico's gross domestic product in relation to 20 major trading partners. $1992=100$.

RER5 = Bilateral U.S.-Mexico real exchange rate as nominal exchange rate deflated by the ratio of tradable to nontradable price index. $1980=100$.

RER6 $=$ Same as the above. The reference base year is $1992=100$.

RER7 = Multilateral labor unit cost real exchange is computed as the ratio of the unitary labor cost of the major countries partners and Mexico's unit labor costs. $1980=100$.

RER $8=$ Multilateral labor unit cost real exchange computed as the above. $1992=100$.

RER9 $=$ Multilateral wage ratio real exchange rate same as the above except unit labor cost are adjusted by productivity and the weights are based on trade. $1992=100$.

RER $10=$ Same as the above except the weights are based on gross national product of Mexico's 20 major partners. 1992=100.

RER11 = Multilateral interest rate real exchange rate computed as the ratio of the interest rate and the weights are based on trade. $1992=100$.

RER $12=$ Same as the above except the weights are based on GDP. $1992=$ 100 .

\section{References}

Abeysinghe, T. and L. Kok-Hong (1992). Singapore's Strong Dollar Policy and Purchasing Power Parity. Singapore Economic Review, 37, April 1992, pp. 70-79.

Bahmani, O. (1993). PPP Based on Effective Exchange Rate and Cointegration: 25 LDCs Experience with its Absolute Formulation. World Development, 21, pp. 1023-1031. 
Baillie, R. and P. McMahon (1993) The Foreing Exchange Market: Theory and Econometric Evidence. Cambridge University Press, New York.

Banco de México (1990-2000). Indicadores Económicos, varios volúmenes.

Cassel, G. (1918). Abnormal Deviations in International Exchanges. The Economic Journal, 28, pp. 413-415.

Conejo, C. and M. P. Shields (1993). Relative PPP and the Long Run terms of Trade for Five Latin American Countries: A Cointegration Approach. Applied Economics, 25(12), pp. $1511-1515$.

Dickey, D.A. and W.A. Fuller (1979). Distribution of the Estimators for Autoregressive Time Series with a Unit Root. Joumal of the American Statistical Association, 74, pp. 427-321.

Dickey, D.A. and W.A. Fuller (1981). Likelihood Ratio Test for Autoregressive Time Series with a Unit Root. Econometrica, 49, pp. 1057-1072.

De la Cruz, J. (1994). La Evolución Económica de Mexico: Un Análisis de Cointegración. Tesis Doctoral, Iowa State University.

Engel, R.R. and J.D. Hamilton (1990). Spectral Regression for Cointegrated Time Series. In William Barnett (Ed.). Nonparametric and Semiparametric Methods in Economics and Statistics. New York: Cambridge, University press.

Flynn, N.A. and J.L. Boucher (1993). Test of Long-Run Purchasing Power Parity: Using Alternative Methodologies. Journal of Macroeconomics, 15, pp. 109-122.

Goal, J.A. (1994). Spurious Regression, with AR(1) Correction and Unit Root Pretest. John Hopkins University, Mimeo.

Harbeler, C.M. (1975). Asymptotics for Linear Process. University of California, Irvine, Mimeo.

Harberger, S.R. (1986). Statistical Inference in Regression with Unit Roots. University of Rochester, Mimeo.

Hansen, B. (1990). A Power full, Simple Test for Cointegration Using Cochrane-Orcutt. University of Rochester. Mimeo.

Isard, P. (1977). How Far Can we Push the Law of One Price? American Economic Review, 67 , pp. 942-948.

Isard, P. (1987). Lessons form Empirical Models of Exchange Rates. Staff Papers, International Monetary Funds, 34, pp. 1-28.

Kim, Y. (1990). Purchasing Power Parity: Another Look at the Long Run Data. Economics Letters, 32, pp. 334-339.

Liu, P. (1992). Purchasing Power Parity in Latin America: A Cointegration Analysis. Weltuirtschafliches Archiv, 128(4), pp. 662-680.

Mahdavi, S. and S. Zhou (1994). Purchasing Power Parity in High Inflation Countries: Further Evidence. Journal of Macroeconomics, 16(3), pp. 403-422.

McNown, R. and M. Wallace (1989). National Price Levels, Purchasing Power Parity, and Cointegration: A test of Four High Inflation Economies. Journal of International Money and Finance, 8(4), pp. 533-545.

Masih, R, and M.A. Masih (1995). Temporal Causality and the Dynamic Interactions among Macroeconomic Activity within a Multivariate Cointegrated System: Evidence from Singapore and Korea. Weltwirtschafliches Archiv, pp. 265-285.

Neary, P. (1988). Determinants of the Equilibrium Real Exchange Rate. American Economic Review, 78. pp. 210-215.

Officer, J.M. (1980). A note on estimation, inference and Forecasting of Time Series Subject to Changes in Regime. University of Rochester. Mimeo.

Phillips, P.C. (1987). Time Series Regression with Unit Roots. Econometrica, 2, pp. 277301.

Phillips, P.C. and P. Perron (1988). Testing for a Unit Root in Time Series Regression. Biometrica, 75, pp. 335-346.

Pérez-López, A. (1995). La Paridad de Poder de Compra en México. Cuaderno de trabajo, No. 23, Banco de México. 
Revista Mexicana de Economía y Finanzas, Vol. 3, No. 3 (2004), pp. 277-301 301

Perron, P. (1989). The Great Crash, The Oil Price Shock, and The Unit Root Hypothesis. Econometrica, 57, pp. 1361-1401.

Said, S.E. and D.A. Dickey (1984). Testing for Unit Root in Autoregressive Moving Average Models of Unknown Order. Biometica, 71, pp. 599-607.

Stockman, J.H. (1987). Asymptotic Properties of Least Squares Estimators of Cointegrating Vectors. Econometrica, 33 p. 161-181. 